\title{
Significance of Bonded Logistics Parks in China, Enabling Indian Retail Industry for Effective Logistics
}

\author{
Arivalagan R, V. A. Anand
}

\begin{abstract}
Multiple handling and resting of materials at different points in the flow of Supply Chain has come into the limelight in the recent time due to severe cost pressure for the reduction and savings of Logistics costs. The ease of material movement is been on a large focus in-order to achieve cost savings and to have a win-win situation for both the Suppliers and the Customers. With the effect of globalization, the foreign Suppliers are exporting goods to the consignee country by paying customs duty and in-turn the consignee on the receiving end pays import customs duty for the consumption of the goods and on top of it pays an additional storage and handling charges for the Warehousing and Distribution activity in the consignee country. This makes the logistics costs to go up. To tackle this challenge and complexity in the Logistics system, major economies are introducing FTZ - Free Trade Zones or Logistics Parks in major cities. These Free Trade Zones are backed up the concern country's government and customs authorities. With lot of initiatives coming from the government side but still there is a huge demand gap for these Free Trade Zones or Logistics Parks and many of them are underutilized or rather unoccupied. Still many of the Consumers are relying upon traditional CFA Custom Freight Agents or other warehouses for getting this service done. But they are missing a big picture of Logistics Cost Savings, Transit time reduction in transferring the goods and the major advantage in tax rebates.
\end{abstract}

At this backdrop, this paper address the major advantage of using the Bonded Logistics Park, developed and promoted by the People's Republic of China by analyzing the data of an Indian customer who is sourcing more than $70 \%$ from China.

Keywords: Logistics Park, BLP, Bonded Logistics Park, Bonded Warehouse, Export Processing Zone, International Distribution practice.

\section{INTRODUCTION}

The Free Trade Zones are the one which was established and developed with the State Council's approval and are termed as a special economic zone supervised by the Customs of the respective country. There are primarily three major functions of bonded zones;

- Warehousing - Bonded Warehousing,

Manuscript received on February 10, 2020

Revised Manuscript received on February 20, 2020.

Manuscript published on March 30, 2020.

* Correspondence Author

Arivalagan R, Research Scholar, Dept. of Logistics Management, Alagappa University, Karaikudi, India. Email: r.arivalagan@gmail.com

Dr. V. A. Anand, Assistant Professor, Dept. of Logistics Management, Alagappa University, Email: drvaanand@gmail.com

(C) The Authors. Published by Blue Eyes Intelligence Engineering and Sciences Publication (BEIESP). This is an open access article under the CC BY-NC-ND license (http://creativecommons.org/licenses/by-nc-nd/4.0/)
- Export Processing,

- Entrepot trade

With the Foreign Trade and Economic Cooperation, policies are in practice, the Customs operations in the respective country carries out a closed-end management process operation in the bonded zones. The key takeaway from the above policy is, once the cargo from a foreign country enters a Free Trade Zone or a Bonded Logistics Park, they are subject to the Customs management. Whereas, once domestic goods enters the Bonded Logistics park, they are regarded as these goods are meant for exports and exporter can get a tax rebate of refund after the goods leave the Bonded Logistics park, which is China in this case. The goods in the bonded logistics park will be treated as if it is parked inside a foreign country unless until it is customs cleared during the export to the final delivery country. For example, a cargo sitting in a BLP-Bonded Logistics Park in Yantian, China will be treated as a foreign country and not in China, literally.

The Chinese government has established and developed 13 main BLPs in and around the country and they have make sure that these BLP's were all well connected to the nearest major ports for logistics movements. The BLP's are located at Shanghai, Shenzhen, Tianjin, Guangzhou, Dalian, Haikou, Zhangjiagang, Fuzhou, Ningbo, Qingdao, Xiamen, Shantou and Zhuhai.

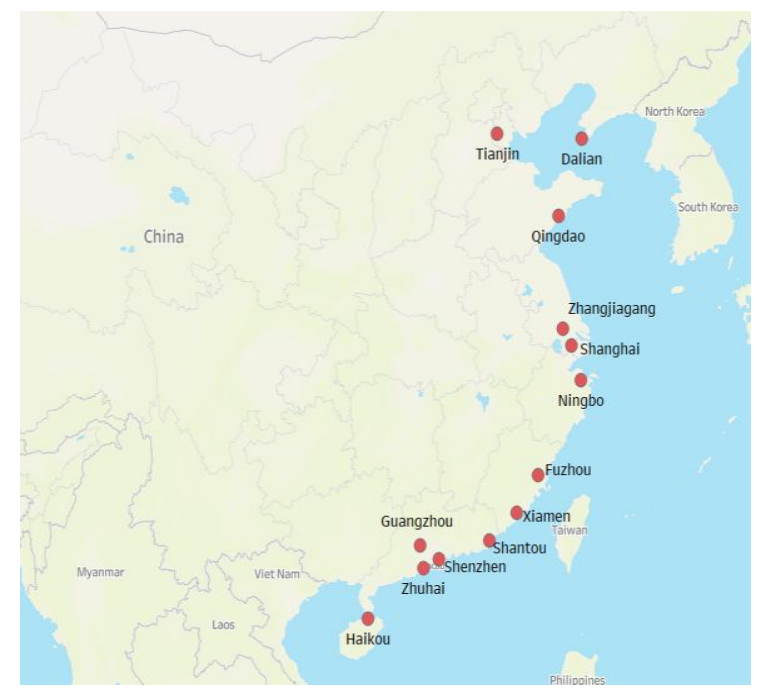

Fig. 1.BLP Locations in China

These BLP's - Bonded Logistics Parks areas are not true FTZ - Free Trade Zones but these are exceptional zones that relish taxation benefits by being "within China but outside the Customs". 
In other words, the goods are on Chinese soil, but not consumed for China.

The advantage and benefits of using these BLP - Bonded Logistics Parks are:

- Goods entering the BLPs from Suppliers outside the parks are considered as for export and export VAT reimbursement can be applied.

- Goods within the BLPs can be distributed freely and no value-added tax and consumption tax is paid. This might be very useful for processing.

- Goods going out of the bonded logistics parks to China are considered as imports. They has to be declared to the Customs by the Suppliers within or outside of the Logistics parks and are subject to tax or exempted from tax, depending on the arrangement.

\section{LITERATURE REVIEW}

Yi He ; Guojun Ji ; Aihua Liu states that bonded zones in China takes an advantage in logistics space for storing and re-distributing the goods in Supply Chain flow making it one of the most advantageous option for Tax redemptions Bonded Logistics Park and neighboring Bonded Zone development mode and game analysis, 2008

Free Trade Zones - FTW or Export processing zones (EPZs) are the areas inside the country, which provides rewards and benefits to the Suppliers and act as a barrier-free environment to stimulate economic growth by attracting foreign investment for export-oriented production - Nicolas Papadopoulos and Shavin Malhotra, 2007

The change in the process of manufacturing to foreign countries and recent development in global policies, regulations and procedures for a transformed understanding of Bonded Logistics Parks and Free Trade Zones from the perspective of the extended enterprise. These BLP's offers a significant potential impact on the efficiencies of global supply chains, BLP's in such a context have not been spread that depth in academic literature - Caitlin N. Benton, Madeline Napier, M. Ali Ülkü, 2016

The Free Trade Zones and industrial clusters have created vital offerings to China's economic success. Organized with the abundant industrial clusters, the Free Trade Zones and Bonded Logistics Parks have funded significantly to gross domestic product, employment, exports and attraction of foreign investment. These special economic zones have also played an important role in bringing new technologies to China and up-to-the-minute management practices - Douglas Zhihua Zeng, 2011India's economic prospective and Free Trade Zones rose to a whopping 1.1 billion population and a GDP per capita of US\$3,400. India is a rising power that no international company can afford to ignore. In 2015, the International Monetary Fund (IMF) reported India's GDP to be US\$3.63 trillion in terms of purchasing power parity, ranking fourth in the world. Hence, there is an immense opportunity in India to promote the export-oriented processing zones and Bonded Logistics parks within the manufacturing sector through Special Economic Zones or SEZs - Bhat T.P. , 2011

\section{PROBLEM DESCRIPTION}

With that well-articulated as above on the usage of Bonded Logistics parks in China, now let's delve into the core topic on the usage of Bonded Logistics Park in a Retail Supply Chain. A Retail giant in India is sourcing more than $70 \%$ of its volume (annual) from China. Currently the company has more than 74 suppliers located in China out of 141 globally - which has spread into $80 \%$ of the volume comes from South China and $20 \%$ from North China. The company is currently sourcing from 13 locations in China and using more than 4 CFA's - Carrying and Forward Agents.

\section{As-Is situation \\ Customer in India places order to the Chinese suppliers \\ Chinese supplier produces the order and take the Shipment to Hong Kong to get the tax rebate and back to China CFA \\ CFA consolidate the shipments and send back to the ports (Hong Kong or Shenzhen/Shanghai ) for export \\ Chinese suppliers files the tax rebate after fixed time \\ With the above cited problem, this paper articulates the possible ways to cut down the Transit time in moving shipments from China to Hong Kong and back again to China from Hong Kong, eliminate the unwanted spend in logistics cost, ways to get the tax rebates for the Chinese suppliers in a quick and short durations.}

\section{RESEARCH OBJECTIVES}

The main purpose of this research is to promote and leverage the usage of the established BLP's- Bonded Logistics parks in China. This is made possible with the help of the data research collected from an Indian retail giant for analyzing the said objectives.

\begin{tabular}{|l|}
\hline With BLP in place \\
\hline Customer in India places order to the Chinese suppliers \\
\hline $\begin{array}{l}\text { Chinese supplier produces the order and take the Shipment } \\
\text { Chinese BLP's }\end{array}$ \\
\hline $\begin{array}{l}\text { Shipments gets consolidated in the BLP's and ready for } \\
\text { exports }\end{array}$ \\
\hline Chinese suppliers will get tax rebates immediately \\
\hline $\begin{array}{l}\text { Transit time in moving shipment from China - Hong Kong } \\
\text { and back to China from Hong Kong will be cut down. }\end{array}$ \\
\hline
\end{tabular}

\section{RESEARCH METHODOLOGY}

\section{a) Area of the study}

The research paper focus on the suppliers in China and the geography is limited to China with Shenzhen, Guangzhou, Qingdao, Xiamen, Zhuhai, Shanghai, Ningbo, Tianjin, Fuzhou, Haikou as a major source of Supplies. Then the focus has turned to link all the above said Supplier location to the nearest BLP-Bonded Logistics Park for Consolidation and other benefits, which is showed in the below figure for visual representation;

\section{Blue Eyes Intelligence Engineering \& Sciences Publication}




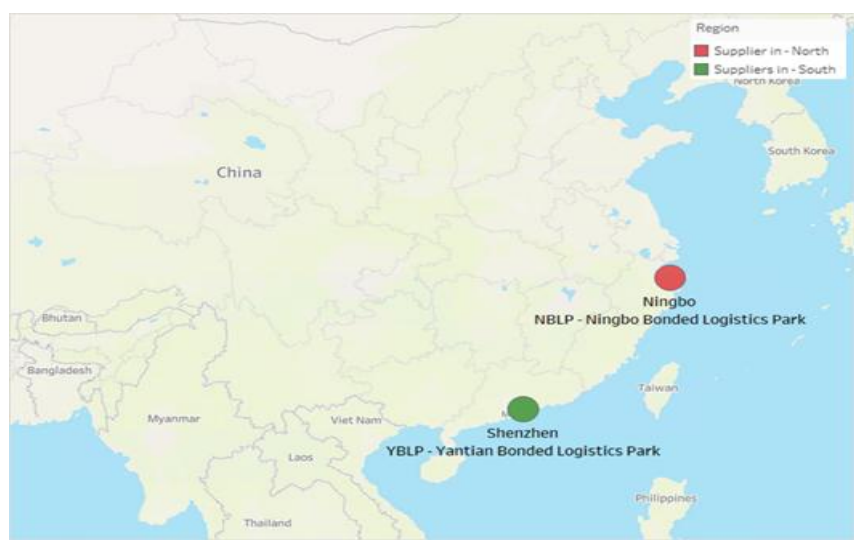

Fig. 2.Supplier's Cluster Using BLP in China

\section{b) Sources of data}

The shipment data over a period of 12 months ( 1 year) is considered for the study to analyses the cost savings and other benefits. The data cleansing and fine-tuning is done using continuous follow with the company's logistics team to maintain data accuracy.

\section{c) Sampling Design and Tools for analysis}

For the modelling purposes for analysis, 12 months shipment data was collected for the company linking a data period of August 2018 to August 2019 with 24,682 records containing 740 containers.

- Data Cleansing is done on the collected Raw data to design the data in the required method to input into the data model.

- Shipment level data is built by annualizing the demand going towards each destination nodes or cities

- Basic data analysis is analyzed to view the baseline logistics network, Volume distributed across the network, concentration of customer points to be served etc.

- Container stuffing modelling tool is built up in Microsoft excel using the maximum allowable safest volume that can be go into a type of a container to get the maximum utilization.

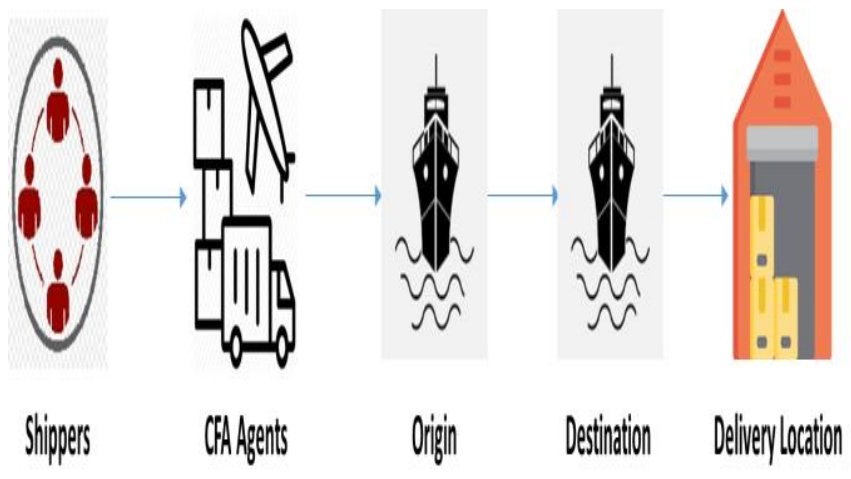

Fig. 3.Logistics Network before BLP introduction

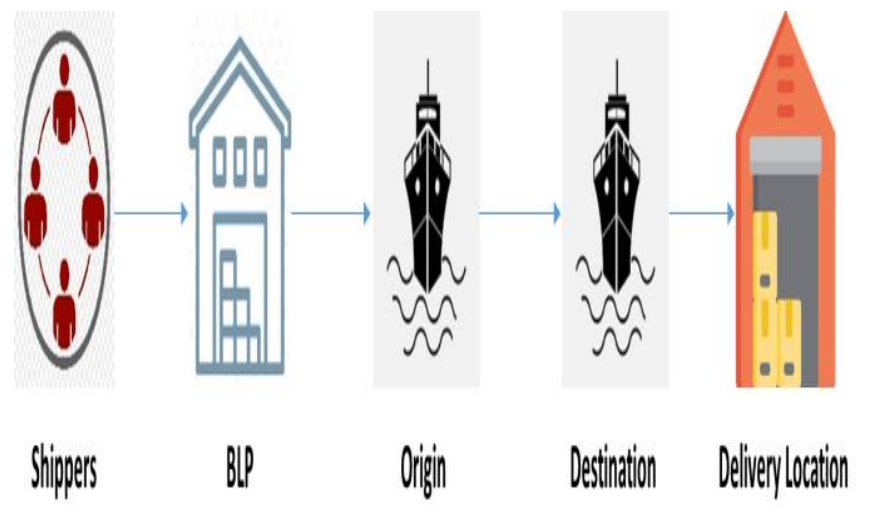

Fig. 4.Logistics Network after BLP introduction

\section{ANALYSIS AND FINDINGS}

1. Multiple simulation on routing and flow of cargo is tried out using the collected data and cost for storage, handling and transportation is derived using the rates collected.

2. The foreign customers will not pay local taxes or any duty on the imported cargos until the cargo is dispatched from the Bonded Logistics park to the customers locations.

3. The analysis and the use of Bonded Logistics Park, gives a favorable result of $11 \%$ savings over the baseline.

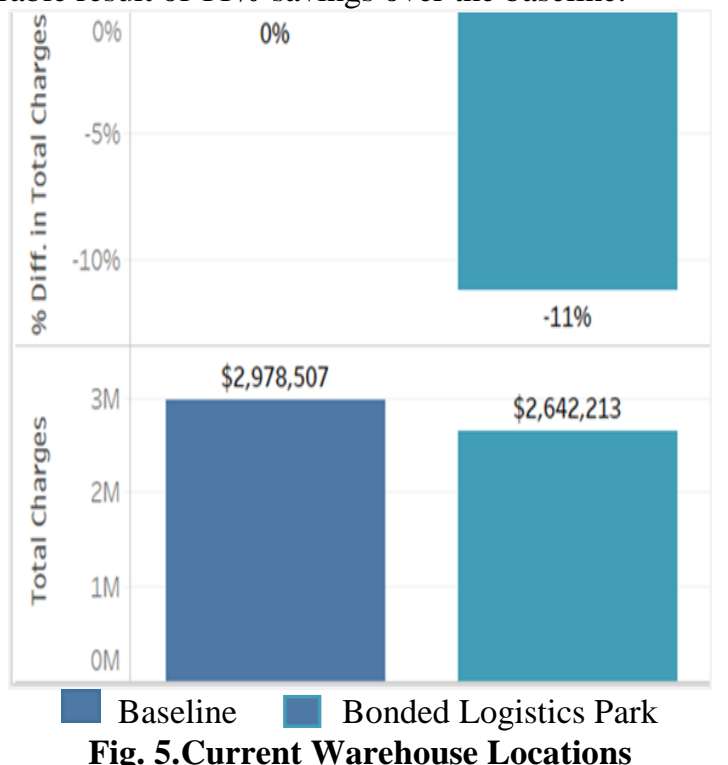

4. The time taken for the Supplier in China for getting the Tax re-funds reduces $60 \%$ from the baseline.

5. Optimized network with geographic advantage over the international trade

6. Cross border trucking network to South East Asia and Hong Kong with the help of these Bonded Logistics parks.

\section{CONCLUSION}

Handling and Storage is being the part and parcel of any logistics activity. Considering todays though and fierce competition on logistics cost, organization's focus on cost savings is playing a major role in finding opportunities for the same. With steps from government interms of incentives and policy framework coming into picture for ease of doing business, now its turn for the suppliers and customers to make use of these in order to leverage the savings. 
One such initiative is by promoting Bonded logistics parks in most of the highly demand geographies which will benefit both the domestic suppliers and the international customers. These parks not only benefit interms of cost but also help in a major way to cut down the unwanted delays happening in the logistics chain by curtailing multiple handlings. Another benefit of these parks will also results in minimizing the losses and damages that happened in various touch points of the logistics chain. Thus with the help of the research citied in this paper it is evident that there is a sure shot benefit for any international organization doing business in china. This will also results in more foreign investments and job creations.

\section{REFERENCES}

1. Chinese Bonded Areas: Choosing the Right Location, By Michael Pfaar and Xiaodan Wang

2. http://www.ey.com/GL/en/ Services/Tax/International-Tax

3. http://www.ey.com/GL/en/ Services/Tax/International-Tax

4. Bonded Logistics Case Study - ICS Global Services Limited http://www.icsglobalservices.co.uk/

\section{AUTHORS PROFILE}

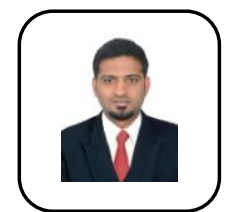

Arivalagan $\mathbf{R}$ is an Electronics \& Communication Engineer and holds Masters in Business Administration. He has an overall experience of around 11years in the field of Supply Chain and Logistics Management. After graduation, he has started his career as a Procurement Engineer in China-Shenzhen for 4years where he has gained knowledge on Global Sourcing, Logistics, and Export-Imports. Later he has joined Accenture Services ltd as a Business Advisor in Global procurement. Later he joined CII-Confederation of Indian Industry as a Supply Chain Consultant. He has designed Supply Chain Maturity Model for assessing Indian Industries and audited more than 85 warehouses across India. His core strength includes Warehouse optimization and designs, Network Optimization, Inventory Optimization etc.

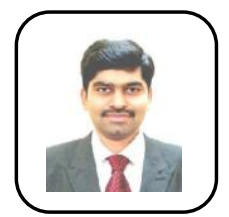

Dr Anand V.A is an Assistant Professor in Alagappa University, Karaikudi in Department of Logistics Management. He comes with an industry experience of more than 4 years working for a major IT organization in India and supporting various project both in India and abroad. He is a veteran in Systems and Entrepreneurship management. With that as a background, he has joined Alagappa University, Karaikudi in 2016 and passing on his knowledge and experience by teaching Logistics to various students. Dr Anand is having more than 9 years of teaching experience. He is also mentoring and providing guide ship to various part time $\mathrm{Ph} . \mathrm{D}$. scholars and helping them in their research activity. His core strength includes Network Optimization, Designing Warehouse and Logistics parks etc. 